\title{
Tumor Promotion
}

National Cancer Institute

\section{Source}

National Cancer Institute. Tumor Promotion. NCI Thesaurus. Code C19098.

The second step in two-stage carcinogenesis: the conversion of an initiated (premalignant) cell to malignancy. 